\title{
PROJECT MANAGEMENT INFORMATION SYSTEMS: AN EMPIRICAL STUDY OF THEIR IMPACT ON PROJECT MANAGERS AND PROJECT SUCCESS
}

\author{
Louis Raymond \\ Université du Québec à Trois-Rivières, \\ P.O. Box 500 \\ Trois-Rivières QC \\ Canada G9A 5H7 \\ louis.raymond@uqtr.ca \\ François Bergeron \\ Université Laval \\ francois.bergeron@fsa.ulaval.ca
}

\begin{abstract}
Project management information systems (PMIS) usually acquired by organizations as software packages are meant to provide managers with the decision-making support needed in planning, organizing and controlling projects. However, the actual contribution of PMIS to project success or performance is still unknown. The purpose of this study is to empirically assess the quality of the PMIS presently used in organizations and to examine their impact on project managers and project performance, based on a model of PMIS success model. This model is composed of five constructs: the quality of the PMIS, the quality of the PMIS information output, the use of the PMIS, the individual impacts of the PMIS and the impacts of the PMIS on project success. Analysis of questionnaire data obtained from 39 project managers confirms the significant contribution of PMIS to successful project management. Improvements in effectiveness and efficiency in managerial tasks were observed here in terms of better project planning, scheduling, monitoring, and control. Improvements were also observed in terms of timelier decision-making. Advantages obtained from PMIS use are not limited to individual performance but also include project performance. These systems were found to have direct impacts on project success, as they contribute to improving budget control and meeting project deadlines as well as fulfilling technical specifications.
\end{abstract}

Keywords: PMIS, project management information system, project manager, IS success, IS impacts, project success. 


\title{
PROJECT MANAGEMENT INFORMATION SYSTEMS: AN EMPIRICAL STUDY OF THEIR IMPACT ON PROJECT MANAGERS AND PROJECT SUCCESS
}

\begin{abstract}
Project management information systems (PMIS) usually acquired by organizations as software packages are meant to provide managers with the decision-making support needed in planning, organizing and controlling projects. However, the actual contribution of PMIS to project success or performance is still unknown. The purpose of this study is to empirically assess the quality of the PMIS presently used in organizations and to examine their impact on project managers and project performance, based on a model of PMIS success model. This model is composed of five constructs: the quality of the PMIS, the quality of the PMIS information output, the use of the PMIS, the individual impacts of the PMIS and the impacts of the PMIS on project success. Analysis of questionnaire data obtained from 39 project managers confirms the significant contribution of PMIS to successful project management. Improvements in effectiveness and efficiency in managerial tasks were observed here in terms of better project planning, scheduling, monitoring, and control. Improvements were also observed in terms of timelier decision-making. Advantages obtained from PMIS use are not limited to individual performance but also include project performance. These systems were found to have direct impacts on project success, as they contribute to improving budget control and meeting project deadlines as well as fulfilling technical specifications.
\end{abstract}

\section{INTRODUCTION}

Globalization and the internationalization of markets have increased competitiveness pressures on business enterprises. This has led companies to engage in projects that are critical to their performance, if not their survival. These projects, common in industries such as engineering services, information technology, construction, and pharmaceutical have one thing in common: they need to be managed, that is, they need to be planned, staffed, organized, monitored, controlled and evaluated (Liberatore and Pollack-Johnson, 2003). In order to succeed, companies must deliver projects on time and within budget, and meet specifications while managing project risk. While large amounts of time and resources are dedicated to selecting and designing projects, it remains of paramount importance that projects be adequately managed in organizations if they are to achieve their performance objectives. In this regard, what are we to think of the management of the Athens Olympic Games, first estimated at a cost of 3 billion $€$, that finally ended costing 12 billion $€$ (Scotsman.com, 2005)? Of the Canadian Arm Registry, an information system first estimated at "no more than 2 million dollars a year" in 1995, that finally cost close to one billion \$ (CAN) ten years later (CTV.ca News Staff, 2006)? Or of the $275 \%$ cost overrun in Boston's Big Dig (Central Artery/Tunnel Project), totaling 11 billion \$ (US) as of 2006 (Wikipedia, 2007)? Thus, "project management remains a highly problematical endeavour" (White and Fortune, 2002).

In the information technology (IT) industry, Gartner Research estimates that $75 \%$ of large IT projects managed with the support of a project management information system (PMIS) will succeed, while $75 \%$ of projects without such support will fail (Light et al., 2005). Using PMIS to manage 
projects, while not sufficient to insure project success, has thus become a necessity. Project management, which has long been considered an important characteristic of successful companies (Peters and Waterman, 1982), is more than ever necessary to efficiently and effectively manage these projects and to support project managers in their decision-making. As powerful project management software has been developed and diffused in all types of organizations, be they large or small, private or public, they are meant to make a significant contribution to project management.

Similar to other information systems (IS), a successful PMIS should have individual impacts in terms of satisfied users and effective use. But a successful PMIS should also have organizational impacts, that is, impacts on project success in terms of respecting budget, schedule and specifications. While PMIS are increasingly used by project managers in all types of industry, not much is known on the characteristics of these systems that contribute to project success. Thus the purpose of this study is first, to empirically assess the quality of the PMIS presently used in organizations and second, to examine their impact on project managers and project performance.

\section{RESEARCH BACKGROUND AND MODEL}

In the project management literature, IT-based information systems were deemed early on to be essential to project managers in support of their planning, organizing, control, reporting and decision making tasks. As defined by Cleland and King (1983), the basic function of a PMIS was to provide managers with "essential information on the cost-time performance parameters of a project and on the interrelationship of these parameters". The nature and role of a PMIS within a project management system, as presented in Figure 1, have been characterized as fundamentally "subservient to the attainment of project goals and the implementation of project strategies" (Raymond, 1987).

Notwithstanding the theoretical and practical importance of PMIS to the project management field, there have been as of yet few studies on the actual use and impacts of these systems, thus highlighting the need to extend project management theory in relation to the developing practice in this regard (Winter et al., 2006). Empirical studies of PMIS have been mostly limited to describing the demographics of project management software usage (Liberatore and Pollack-Johnson, 2003) and to evaluating specific applications of these systems or software modules to support project management tasks such as planning (Amami et al., 1993), communicating and reporting (Brackett and Isbell, 1989), managing risks (Jaafari, 1996), scheduling (Herroelen, 2005), estimating costs (Love and Irani, 2003), and managing documents (Amami and Beghini, 2000). Project management software usage has also been found to have many drawbacks and limitations, both in theory when compared to an ideal PMIS by researchers (Jaafari and Manivong, 1998) and in practice as perceived by project managers (White and Fortune, 2002). 
Figure 1. The PMIS within the project management system (adapted from Raymond, 1987).

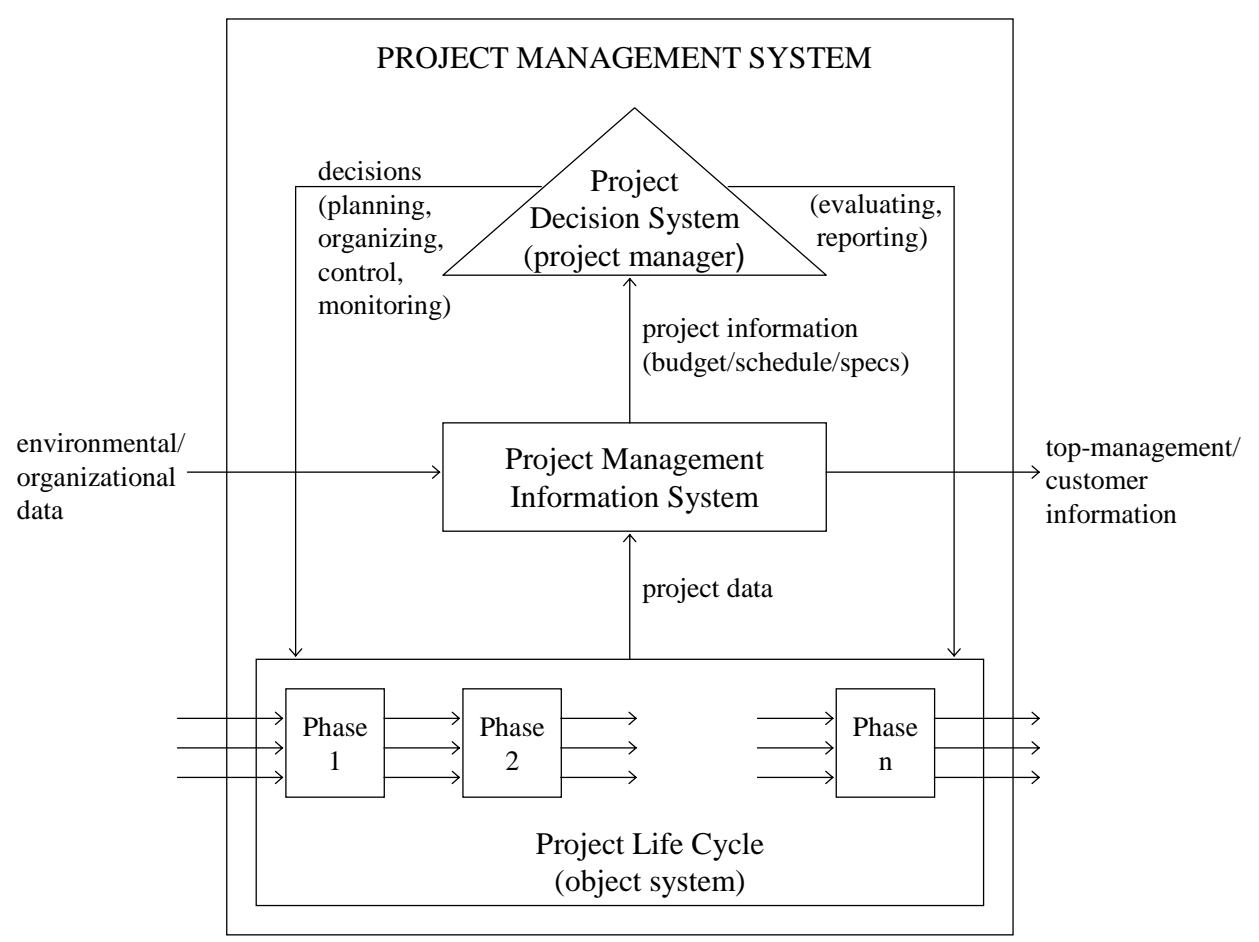

An IS-based conceptualisation and definition of project management software facilitates the import of knowledge from the IS field or discipline, knowledge that can provide a deeper understanding of the PMIS usage phenomenon and help in answering questions on the factors that explain the use and non use of PMIS, and on the actual impacts of these systems on project managers and project performance. This study will thus be founded on the recurrent constructs of antecedents and consequences of IS use developed in DeLone and McLean's (1992) IS success model (ISSM), later updated (DeLone and McLean, 2003), and in Davis' (1989) technology acceptance model (TAM) (Davis et al., 1989). These models stand out by the continuance of their constructs, after a review of theories and models of IS use that focused on their chronological examination and their crossinfluences and convergences. The ISSM incorporates information quality and system quality as antecedents of IS use, leading to individual IS impacts, that is, on users and their work (e.g., in regard to their effectiveness), and in turn to organizational impacts (e.g., in regard to business strategy and performance). While the TAM explains IS use in a similar manner by the system's perceived usefulness and perceived ease of use. Both the ISSM and the TAM offer widely accepted and validated representations and explanations of the IS use phenomenon (Larsen, 2003; Lee et al., 2003; Rai, 2002). 
Our objective is thus to improve our understanding of the impacts of PMIS on project managers and on project performance. More specifically, one intends to ascertain the success of these systems, i.e., their level of use by project managers, as determined by the quality of PMIS and of the information they provide. One will also ascertain to what extent PMIS contribute to the successful completion of projects through their individual and organizational impacts. Indeed, one aims to verify if the use of a PMIS is related to efficiency, productivity and effectiveness of a project manager, and to the performance of the project itself. Thus, the following research questions: What are the main determinants of the success of the PMIS currently used? Does the use of PMIS increase the efficiency, productivity and effectiveness of project managers? And what is the contribution of the PMIS to project success?

Figure 2. Research model on project management IS success.

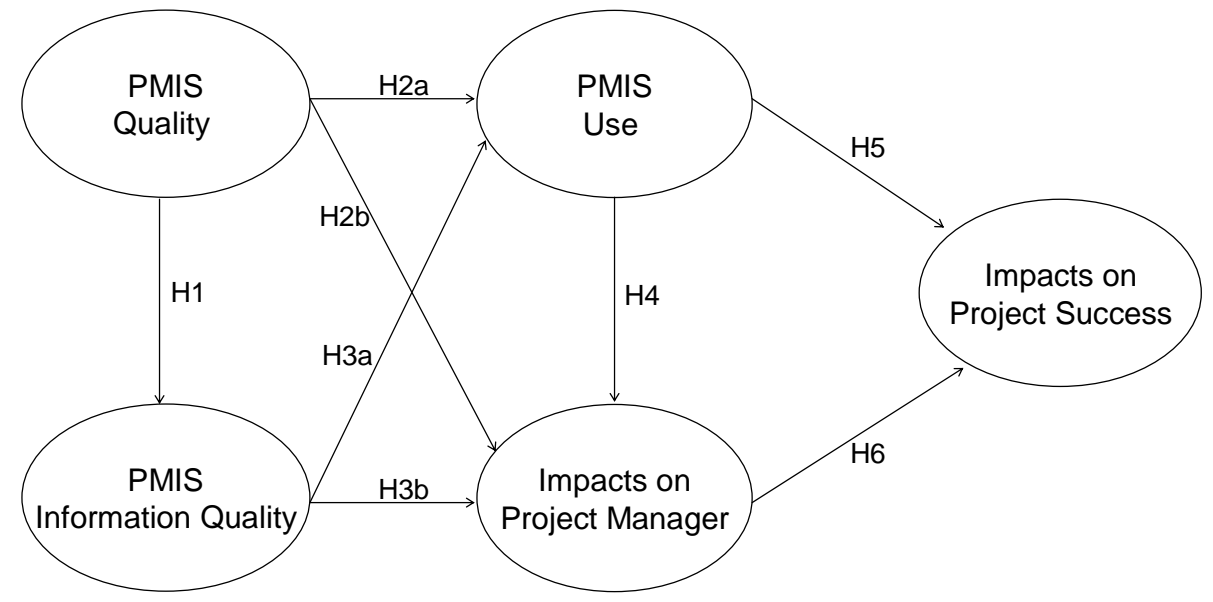

Given the research questions, an adaptation to - and specification for - project management of the ISSM and the TAM was deemed to be most appropriate. As presented in Figure 2, the model as adapted and specified is composed of five constructs, namely the quality of the PMIS, the quality of the PMIS information output, the use of the PMIS, the individual impacts of the PMIS and the impacts of the PMIS on project success, linked through research hypotheses that follow.

Hypothesis 1: Greater PMIS quality is associated to greater quality of information output by the system. This first hypothesis is based on empirical evidence linking the technical and service aspects of an information system (e.g., ease of use, response time) to the user's satisfaction with the 
information output by the system (e.g., perceived usefulness, timeliness of the information) (Igbaria et al., 1995).

Hypothesis 2: Greater PMIS quality is associated to greater system use (H2a) and greater system impacts on the project manager $(\mathrm{H} 2 \mathrm{~b})$. In applying IS theory and results to project management, one finds that previous empirical tests of the ISSM and the TAM have shown system quality to positively influence system use and positively affect individual user performance in terms of job effectiveness, quality of work and decision-making (Bergeron et al., 1995; Igbaria et al., 1997; Taylor and Todd, 1995; Weill and Vitale; 1999).

Hypothesis 3: Greater quality of the information output by the PMIS is associated to greater system use (H3a) and greater system impacts on the project manager (H3b). The third hypothesis extends to project management the notion that the managers' use of IT-based information systems and their performance are dependent upon the quality of information provided to them by these systems (Bergeron et al., 1995; Etezadi-Amoli and Farhoomand, 1996; Teng and Calhoun, 1996; Wixom and Watson, 2001).

Hypothesis 4: Greater use of the PMIS is associated to greater system impacts on the project manager. A number of IS studies have demonstrated that the depth and breadth of IS use (e.g., usage dependency, pattern and frequency), if voluntary and appropriate to the task, has positive impacts on users in terms of job performance and decision-making performance (Igbaria and Tan, 1997; Seddon and Kiew, 1994; Torkzadeh and Doll, 1999; Yuthas and Young, 1998).

Hypothesis 5: Greater use of the PMIS is associated to greater impacts of the PMIS on project success. A number of IS researchers believe that the quality and intensity of information system use, and the "full functionality" of this use in particular, are essential to the achievement of desired organizational results or to the realization of anticipated organizational benefits (DeLone and McLean, 2003: 16; van der Meijden et al., 2003).

Hypothesis 6: Greater impacts of the PMIS on the project manager are associated to greater impacts of the PMIS on project success. This last hypothesis is based on IS theory and evidence that the organizational impacts results not only from IS use but also from the individual impacts of the system (Jurison, 1996; Teo and Wong, 1998), i.e. that projects led by more efficient and effective managers, due to their use of a PMIS, tend to be more successful in terms of meeting project schedules, budgets and specifications.

\section{RESEARCH METHODOLOGY}

To test the research model, a survey of 224 project managers and project management consultants was conducted, identified from a list of participants to a project management national conference held in Canada. The questionnaire was sent by e-mail, as electronic surveys allow the 
transmission of more information, they support a better interaction between the researchers and the respondents, and they contribute to a better quality of information, to a faster response cycle and to a reduction in research costs (Tse, 1998; Klassen and Jacobs, 2001). Forty five questionnaires were received, out of which 39 were considered valid, thus a $17.4 \%$ final response rate. Information on the respondent organizations and on the respondents' demographics is presented in Table1.

Table 1. Characteristics of the sample.

\begin{tabular}{|c|c|c|c|}
\hline $\begin{array}{l}\text { Characterization of the respondents } \\
\qquad(n=39)\end{array}$ & $\begin{array}{l}\text { \% of } \\
\text { sample }\end{array}$ & $\begin{array}{l}\text { Characterization of the respondents } \\
\qquad(n=39)\end{array}$ & $\begin{array}{l}\text { \% of } \\
\text { sample }\end{array}$ \\
\hline Sector of respondents' organization & & Project management experience & \\
\hline services & $74 \%$ & more than 30 years & $25 \%$ \\
\hline manufacturing & $13 \%$ & 20 to 30 years & $41 \%$ \\
\hline public sector & $8 \%$ & 10 to 20 years & $31 \%$ \\
\hline construction & $5 \%$ & less than 10 years & $3 \%$ \\
\hline Function & & Specialization domain & \\
\hline project manager/director/coordinator & $51 \%$ & information technology & $46 \%$ \\
\hline proj. manag. consultant/senior advisor & $23 \%$ & engineering & $21 \%$ \\
\hline top-manager (gen. manag., pres., v.-p.) & $13 \%$ & business & $18 \%$ \\
\hline project engineer/analyst & $13 \%$ & other & $15 \%$ \\
\hline Membership in a professional association & & Gender & \\
\hline yes (Project Management Institute mostly) & $85 \%$ & male & $79 \%$ \\
\hline no & $15 \%$ & female & $21 \%$ \\
\hline Education level & & PMIS software used ( $38 \%$ use more than 1 ) & \\
\hline master's degree & $43 \%$ & MS Project & $90 \%$ \\
\hline bachelor's degree & $41 \%$ & Work Bench & $15 \%$ \\
\hline college degree & $16 \%$ & Primavera & $10 \%$ \\
\hline
\end{tabular}


The information quality, system quality and system use constructs were measured by adapting to the specific PMIS context instruments previously developed and validated in a general IS context (Bergeron et al., 1995; Wang and Strong, 1996). The quality of the PMIS was measured with eight items: accessibility, response time, flexibility, ease of use, querying ease, learning ease, systems integration and multi-project capability. Each of items was measured on a five-point scale varying from 1 (low quality) to 5 (high quality). The quality of information was measured with six items: availability, relevance, reliability, precision, comprehensiveness, and security. Each of these items was measured on a five-point scale varying from 1 (low quality) to 5 (high quality).

The use of the PMIS was measured by ascertaining the extent to which various system functions and their associated tools were actually used by project managers. The PMIS functions were divided into five categories. The planning function tools aim at preparing the overall project plan; they include work breakdown structure, resource estimation, overall schedule, Gantt, PERT and CPM. The monitoring function tools are used to regularly assess project progress; they are used for progress reports and curves, and to update operational reports such as completed tasks, percent project completed, effective schedule, remaining tasks and remaining days to complete. The controlling function tools are used to make specific changes to the project; they allow the project manager to finetune forecasts, modify tasks, reassign resources to lower the costs, cancel tasks, and modify the cost of resources. The evaluating function tools are targeted toward project auditing; these tools allow the identification of cost and schedule variations, and tracking the use of resources. The reporting function tools give information on the most basic aspects of the project; they include an overview of the project as well as reports on work-in-progress, budget overruns and task and schedule slippages. A score for each category was obtained by averaging the project managers' use of specific tools. The five categories and their specific number of number of tools are : planning (6), monitoring (7), controlling (6), evaluating (2) and reporting (9). Five-point scales were employed: 1 (never used), 2 (rarely used), 3 (occasionally used), 4 (often used), and 5 (very often used). Five-point scales were employed: 1 (never used), 2 (rarely used), 3 (occasionally used), 4 (often used), and 5 (very often used).

Impacts on the project managers were measured by the perceived effect of the PMIS on the following ten items: improvement of productivity at work, increase in the quality of decisions, reduction of the time required for decision-making, reduction of the time required to complete a task, improved control of activity costs, better management of budgets, improved planning of activities, better monitoring of activities, more efficient resource allocation, and better monitoring of the project schedule (Lalonde and St-Pierre, 2000). A five-point Likert scale was used, varying from 1 (completely disagree) to 5 (completely agree). The impacts of the PMIS on project success was based on the perceived contribution of the PMIS with regard to three performance criteria: respecting 
deadlines, respecting budgets, and respecting quality specifications (Shenhar et al., 1997), using a fivepoint scale varying from 1 (null contribution) to 5 (very high contribution).

\section{RESULTS AND DISCUSSION}

Descriptive results on the antecedents, consequences and nature of PMIS use by the respondents are presented in Table 2.

Table 2. Characteristics of the respondents' use of PMIS.

\begin{tabular}{|c|c|}
\hline $\begin{array}{c}\text { Respondents' characterization of PMIS } \\
(n=39)\end{array}$ & $\begin{array}{l}\text { \% of } \\
\text { sample }\end{array}$ \\
\hline \multicolumn{2}{|l|}{ Experience in the use of PMIS } \\
\hline more than 6 years & $36 \%$ \\
\hline 3 to 6 years & $54 \%$ \\
\hline 1 to 3 years & $8 \%$ \\
\hline less than 1 year & $2 \%$ \\
\hline \multicolumn{2}{|l|}{ Most important indicator of PMIS Quality } \\
\hline ease of use & $33 \%$ \\
\hline flexibility & $23 \%$ \\
\hline accessibility & $23 \%$ \\
\hline learning capability & $18 \%$ \\
\hline \multicolumn{2}{|l|}{ Satisfaction with PMIS Quality } \\
\hline very high & $13 \%$ \\
\hline high & $48 \%$ \\
\hline \multicolumn{2}{|l|}{$\begin{array}{l}\text { Project Manager work indicator most } \\
\text { impacted by PMIS }\end{array}$} \\
\hline better monitoring of activities & $46 \%$ \\
\hline better planning of activities & $41 \%$ \\
\hline increase in productivity at work & $39 \%$ \\
\hline improvement in the quality of decisions & $20 \%$ \\
\hline better control of activity costs & $18 \%$ \\
\hline better allocation of resources & $15 \%$ \\
\hline
\end{tabular}

\begin{tabular}{lc}
\hline $\begin{array}{c}\text { Respondents' characterization of PMIS } \\
(\mathbf{n = 3 9 )}\end{array}$ & $\begin{array}{c}\text { \% of } \\
\text { sample }\end{array}$ \\
\hline Project phase in which PMIS use is high & \\
initiation & $36 \%$ \\
planning & $72 \%$ \\
realization & $67 \%$ \\
termination & $28 \%$ \\
Most important indicator of Info. Quality & \\
$\quad$ reliability & $44 \%$ \\
$\quad$ relevance & $21 \%$ \\
accuracy & $18 \%$ \\
availability & $18 \%$ \\
Satisfaction with Information Quality & \\
$\quad$ very high & $18 \%$ \\
$\quad$ high & $48 \%$ \\
Impact of PMIS on project manager's work & \\
$\quad$ very high & $13 \%$ \\
$\quad$ high & $51 \%$ \\
Project Success indicator most impacted by & \\
PMIS & \\
$\quad$ meeting deadlines & $59 \%$ \\
respecting budgets & $41 \%$ \\
$\quad$ meeting project specifications & $10 \%$ \\
\hline
\end{tabular}




\subsection{Test of the measurement model}

To test the multivariate relationships hypothesised by the research model, structural equation modelling was used. The partial-least-squares (PLS) method was chosen for its robustness as it does not require a large sample or normally distributed multivariate data in comparison to covariance structure methods such as LISREL and EQS (Fornell and Larcker, 1981). Figure 3 summarizes the results obtained. The PLS method simultaneously assesses the theoretical propositions and the properties of the underlying measurement model. Note that PLS does not provide goodness-of-fit indices; model fit is rather assessed by the reliability of each construct, the significance of the path coefficients, and the percentage of variance explained $\left(\mathrm{R}^{2}\right)$ for each dependent construct (Gefen et al., 2000).

Figure 3. Results of evaluating the research model with PLS ( $n=39)$.

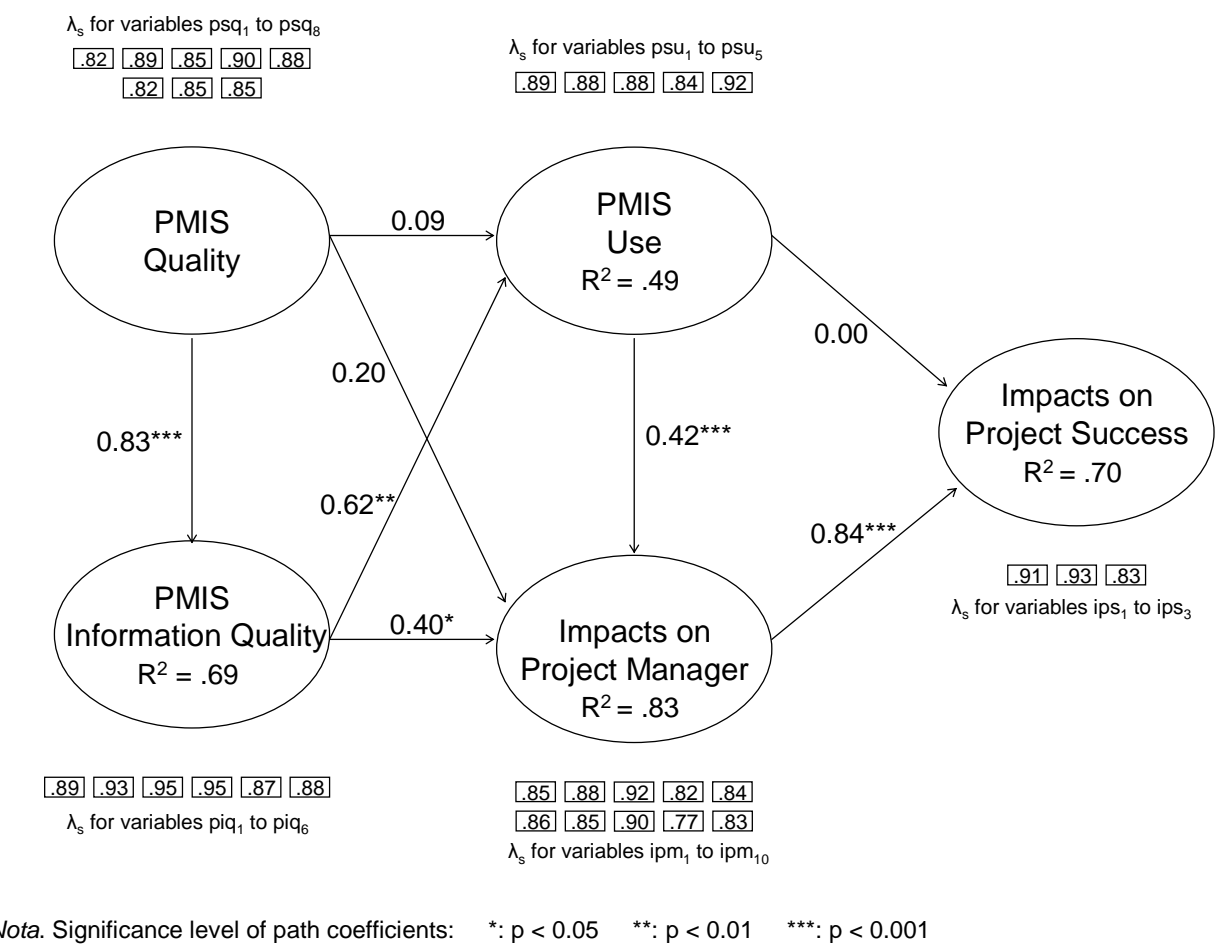

Internal consistency of measures, i.e., their unidimensionality and their reliability must be verified first. The observable variables measuring a non-observable construct (or latent variable) must be unidimensional to be considered unique values. Unidimensionality is usually satisfied by retaining variables whose loadings $(\lambda)$ are above 0.5 , indicating that they share sufficient variance with their 
related construct. The unidimensionality criteria are thus met. Reliability can be verified by considering the value of the rho $(\rho)$ coefficient, defined as the ratio between the square of the sum of the loadings plus the sum of the errors due to construct variance. A $\rho$ greater than 0.7 indicates that the variance of a given construct explains at least 70 percent of the variance of the corresponding measure, as is the case in Table 3 for all constructs in the research model.

Table 3. Reliability and discriminant validity of the research constructs.

\begin{tabular}{lllllll}
\hline \multicolumn{1}{c}{ variable } & $\rho^{\mathrm{a}}$ & 1. & 2. & 3. & 4. & 5. \\
\hline 1. PMIS Quality & .96 & $.74^{\mathrm{b}}$ & & & & \\
2. PMIS Information Quality & .97 & .69 & .83 & & & \\
3. PMIS Use & .95 & .37 & .49 & .77 & & \\
4. Impacts on Project Manager & .96 & .71 & .72 & .66 & .72 & \\
5. Impacts on Project Success & .92 & .46 & .41 & .48 & .71 & .79 \\
\hline
\end{tabular}

${ }^{\text {a }}$ reliability coefficient $=\left(\Sigma \lambda_{\mathrm{i}}\right)^{2} /\left(\left(\Sigma \lambda_{\mathrm{i}}\right)^{2}+\Sigma\left(1-\lambda_{\mathrm{i}}{ }^{2}\right)\right)$

bdiagonal: average variance extracted $=\left(\Sigma \lambda_{\mathrm{i}}^{2} / \mathrm{n}\right)$ sub-diagonals: shared variance $=(\text { correlation })^{2}$

There is also evidence in Table 3 of the convergent validity of the constructs, as their average variance extracted ranges from 0.72 to 0.83 in value. The last property to be verified is discriminant validity. It shows the extent to which each construct in the research model is unique and different from the others. The shared variance between a construct and other constructs (i.e., the squared correlation between two constructs) must be less than the average variance extracted (i.e., the average variance shared between a construct and its measures). Table 3 shows this to be the case for all constructs.

\subsection{Test of the theoretical model}

The research hypotheses are tested by analyzing the direction, the value and the level of significance of the path coefficients (gammas) estimated by the PLS method, as presented in Figure 3. The high percentage of variance explained in each dependent construct, varying from 0.49 to 0.83 , is indicative of model fit.

H1 - A positive and highly significant path coefficient $(\gamma=0.83)$ confirms that the quality of information output by a PMIS is strongly associated to the technical and service aspects of the system, that is, to system quality. From the project manager's point of view, the PMIS can not be considered simply as a "black box" but must be evaluated for its level of sophistication and support provided by the organization's IS function and by the system providers, be they inside or outside the organization.

$\mathrm{H} 2$ - The second hypothesis could not be confirmed as PMIS quality was not found to directly influence the use of the system $(\gamma=0.09)$, nor to its impacts on the project manager $(\gamma=0.20)$. There 
are however a significant indirect effect of system quality on system use (equal to $0.83 \mathrm{X} 0.62$ ) and on impacts on the project manager (equal to $0.83 \times 0.40$ ), that is, through the mediating influence of information quality.

H3 - The third hypothesis, presuming a positive influence of the quality of information provided by the PMIS upon the use of the system and its impacts on the project manager is confirmed. Indeed, the quality of information output is significantly related to the use of the PMIS by project managers (H3a , $\gamma=0.62)$. Path analysis also confirms the existence of a significant relation between the quality of information output and the system's impacts on project managers $(\mathrm{H} 3 \mathrm{~b}, \gamma=0.40)$. Hence a PMIS must provide information on project costs, resources and milestones that is perceived to be relevant, reliable and accurate by project managers if they are to use these systems in their planning, controlling, monitoring and reporting tasks and if they are to be more efficient and effective in accomplishing these tasks.

H4 - Testing the fourth hypothesis confirmed that the use of a PMIS is positively related to its impacts on the project manager $(\gamma=0.42)$. In other words, the use of a PMIS by project managers increases their productivity, effectiveness and efficiency in decision-making due to the quality of the information output by the PMIS. Therefore, using project management software tools that enhance their capacity to plan, control, monitor, audit and report provides tangible benefits to project managers and improves the quality of their work.

H5 - The fifth hypothesis could not be confirmed as no direct relationship was found between PMIS use and the system's impacts on project success $(\gamma=0.00)$. Significant improvements in project performance in terms of meeting deadlines, respecting budgets and meeting specifications can be obtained indirectly however, through the system's impacts on project managers.

H6 - Results confirmed the positive association between the impact of PMIS on the project manager and the impact of PMIS on project success $(\gamma=0.84)$. Hence, the more project managers perceive their task to be positively impacted by their use of project management software, greater is their belief in the positive contribution of this software to the attainment of their projects' performance objectives.

\subsection{Discussion}

The objective of this research is to have a better understanding of the elements that contribute to the impact of a PMIS on project success. The study results are discussed in terms of direct and indirect effects on PMIS project success. To ease the discussion, the elements are grouped in three dimensions: technical (PMIS quality and quality of information), managerial (PMIS use and impact on project manager), and organizational (PMIS impact on project success). 
At the technical level, the first element indirectly influencing the impact of a PMIS on project success is PMIS quality. The system's ease of use, flexibility, response time, learning ease and system integration play an important role in producing quality information, as perceived by the project manager. Indeed, PMIS quality is a strong predictor of the quality of information to be obtained from the system. In the case of a higher-quality PMIS, the information output is more available, reliable, precise, comprehensive and secure. Conversely, a PMIS that produce information of poor quality would be a system that is more difficult to use, less flexible, and less integrated to other organizational information systems used by the project manager and other managers or employees. This means that project information quality requires sophisticated, well-serviced information systems.

The quality of information is directly and strongly related to PMIS use and to the system's impacts on the project manager. Information quality is not an end by itself however, as it leads only indirectly to project success. At the managerial level, it is only through the actual use of the PMIS by and the system's impacts on - the project manager that the quality of information can influence project success. Better quality of information output increases the opportunity of the PMIS being used, which in turn allows the system to have a positive impact on the project manager. As such, the quality of information output by the PMIS leverages the project manager's work as a professional. The latter will feel more professional at work if he or she disposes has access to project information of high quality and uses the system more intensively and more extensively for the planning, control, monitoring and reporting activities. This combination of quality information and extensive use of the system allows the project manager to feel more productive at work and provides improved support for decisionmaking.

This leads us to the final relationship, at the organizational level, specifically the impacts of the PMIS on project success. First, the PMIS itself has no direct influence upon project success; it is only through higher-quality information, extensive use of the system, and individual impacts on the project manager that the system has an effect on project success. While a positive impact on managerial work is essential to project success, greater use of a PMIS does not lead per se to greater impacts on project performance. It is only indirectly, through its contribution to managerial work that this use contributes to project success. In summary, if it is to make a significant contribution to the attainment of project objectives, i.e. to make an impact in terms of project budget, schedule and specifications, a PMIS must first be sufficiently sophisticated and serviced and produce information of sufficient quality. It must then be used with sufficient depth and breadth by project managers and it must have a sufficiently beneficial impact on their work.

It is also worth noting that among the managers who participated in the study, a number indicated strong impacts of the PMIS upon the successful completion of their projects, while others did not. The results indicate that, in general, the latter depended upon a PMIS of lower quality that produced lower quality information; hence they used their system less and were less supported in their project management task. Whereas generally speaking, the former were those for whom the sufficient 
conditions were met, that is, PMIS quality, information output quality, PMIS use and positive impacts on managerial work.

Additional comments can be made in explaining these relationships. First, it is worth noting that a reverse or "feedback" relationship is possible between individual impacts of a PMIS and its use (DeLone and McLean, 2003). As project managers perceive the PMIS to be beneficial to them, it is likely that they will increase their use of the system. Second, other dimensions of project management, related to the organizational environment, evidently play a role in explaining project performance; thus the managers' authority on project activities, their involvement in project design, and their accountability in meeting project objectives are potential success factors other than the PMIS (Bergeron, 1986). Third, another interesting aspect to consider is the possible reluctance of project managers to report "bad news" on a project, and the subsequent effect it could have on the accuracy of project reports and on the assessment of project success (Keil et al., 2007). Finally, as suggested by Shenhar et al. (1997), future studies of PMIS success could evaluate project success or performance from the client's perspective, that is, evaluate if the impacts of the PMIS on project outcomes provide an adequate solution to the client's problem, bring true advantages to the organization in terms of quality of product/services offered, greater output volume, quicker delivery and better strategic positioning, and provide tangible benefits such as increased sales and revenues.

\subsection{Limitations}

This research has limitations however. First, the convenient rather than random nature of the sample and its small size impose care in the generalizing the results of this study to all project managers. Second, an electronic questionnaire limits the number of questions and variables that can be addressed and, being self-administered, is subject to respondent bias. While the items measuring PMIS quality, information quality, PMIS use, PMIS impacts on the project manager and PMIS impacts on project success were placed in separate parts of the questionnaire to mitigate autocorrelation effects, other sources of common method or mono-method biases may yet remain in the survey instrument (Podsakoff et al., 2003).Third, to lessen this bias, one could have used additional objective rather than perceptual measures of the impact of the PMIS on project success; this would have been particularly interesting for the productivity measures. Finally, as the nature of the study is cross-sectional rather than longitudinal, causality cannot be inferred.

\section{CONCLUSION}

The research aim of this study was to determine the actual impacts of IT-based project management information systems upon project managers and project performance. More specifically, 
one objective was to identify the main determinants of PMIS and determine the extent to which these systems assist project managers in terms of increased efficiency, productivity and efficiency. Another objective was to get a better understanding of the contribution of these systems to the success of projects.

Following the conclusions of previous research that PMIS success models should continue to be validated and challenged, the results of this research show that the use of a project management information system is in fact advantageous to project managers. Improvements in effectiveness and efficiency in managerial tasks were observed here in terms of better project planning, scheduling, monitoring, and control. Improvements in productivity were also observed in terms of timelier decision-making. Advantages obtained from PMIS use are not limited to individual performance but also include project performance. These systems were found to have direct impacts on project success, as they contribute to improving budget control and meeting project deadlines as well as fulfilling technical specifications. One can therefore conclude that PMIS make a significant contribution to project success and should continue to be the object of project management research.

\section{References}

Amami M, Beghini G. Project management and communication of product development through electronic document management. Project Management Journal 2000; 31 (2): 6-19.

Amami M, Beghini G, La Manna M. Use of project management information system for planning information systems development projects. International Journal of Project Management 1993; 11 (1): 21-28.

Bergeron F. Factors influencing the use of DP chargeback information. MIS Quarterly 1986; 10 (3): 225-238.

Bergeron F, Raymond L, Rivard S, Gara, M-F. Determinants of EIS use: Testing a behavioral model, Decision Support Systems 1995; 14: 131-146.

Brackett S W, Isbell A-M. PMIS - An integrated approach for the management and distribution of project information. Project Management Journal 1989; 20 (3): 5-10.

Cleland D J, King W R. Systems Analysis and Project Management. New York: McGraw-Hill; 1983.

CTV.ca News Staff. Conservatives move to disarm long-run registry, June 19, 2006, 11:51PM ET, http://www.ctv.ca.

Davis, F D, Bagozzi R P, Warshaw P R. User Acceptance of Computer Technology: A Comparison of Two Theoretical Models. Management Science 1989; 35 (8): 982-1003.

DeLone, W.H. and McLean, E.R. (1992), Information systems success: The quest for the dependent variable, Information System Research, 3 (1), 60-95.

DeLone W H, McLean E R. The DeLone and McLean model of information systems success: A tenyear update. Journal of Management Information Systems 2003; 19 (4): 9-30.

Etezadi-Amoli, J, Farhoomand A F. A structural model of end user computing satisfaction and user performance. Information \& Management 1996; 30 (2): 65-73.

Fornell C R, Larcker D F. Evaluating structural equation models: LISREL and PLS applied to consumer exit-voice theory. Journal of Marketing Research 1981; 18: 39-50.

Gefen D, Straub D W, Boudreau M-C. Structural equation modeling and regression: Guidelines for research practice. Communications of the Association for Information Systems 2000; 4: 1-76.

Goslar M D, Green G I, Hughes T H. Applications and implementation of. decision support systems: An empirical assessment for decision making. Decision Sciences 1986; 17 (1): 79-91. 
Herroelen W. Project scheduling - Theory and practice. Production and Operations Management 2005; 14 (4): 413-432.

Igbaria M, Iivari J, Maragahh $\mathrm{H}$. Why do individuals use computer technology? A Finnish case study. Information \& Management 1995; 29 (5): 227-238.

Igbaria M, Tan M. The consequences of information technology acceptance on subsequent individual performance. Information \& Management 1997; 32 (3): 113-121.

Igbaria M, Zinatelli N, Cragg P, Cavaye A. Personal computing acceptance factors on small firms: A structural equation model. MIS Quarterly 1997; 21 (3): 279-302.

Jaafari A. Time and priority allocation scheduling technique for projects. International Journal of Project Management 1996; 14 (5): 289-299.

Jaafari A, Manivong K. Toward a smart project management information system. International Journal of Project Management 1998; 16 (4): 249-265.

Jurison J. The temporal nature of IS benefits: A longitudinal study. Information \& Management 1996; 30 (2): 75-79.

Keil M, Im. G P, Mähring M. Reporting bad news on software projects: The effects of culturally constituted views of face-saving. Information Systems Journal 2007; 17 (1): 59-87.

Klassen R D, Jacobs J. Experimental comparison of Web, electronic and mail survey technologies in operations management. Journal of Operations Management 2001; 19 (6): 713-728

Lalonde B, St-Pierre A. Microsoft Project 2000: La gestion informatisée de projet. Montréal: Editions Vermette; 2000.

Larsen K.R.T. A taxonomy of antecedents of information systems success: Variable analysis studies. Journal of Management Information Systems 2003; 20 (2): 169-246.

Lee Y, Kozar K A, Larsen K R T. The technology acceptance model: Past, present, and future. Communications of the Association for Information Systems 2003; 12: 752-780.

Light, M., Rosser, B., Hayward, S., "Realizing the Benefits of Projects and Portfolio Management", Gartner, Research ID G00125673, 4 January 2005, p. 1-31.

Liberatore M.J., Pollack-Johnson, B. Factors influencing the usage and selection of project management software. IEEE Transactions on Engineering Management 2003; 50 (2): 164-174.

Love P.E.D., Irani Z. A project management quality cost information system for the construction industry. Information \& Management 2003; 40: 649-661.

Mahmood M A, Medewitz J N. Impact of design methods on decision support systems success: an empirical assessment. Information and Management 1985; 9 (3): 137-151.

Peters T, Waterman D L. In Search of Excellence. New York: Warners Books; 1982.

Podsakoff, P M, MacKenzie S B, Lee J-Y, Podsakoff N P. Common method biases in behavioral research: A critical review of the literature and recommended remedies. Journal of Applied Psychology 2003; 88 (5): 879-903.

Rai, A, Lang S S, Welker R B. Assessing the validity of IS success models: An empirical test and theoretical analysis. Information Systems Research 2002; 13 (1): 50-69.

Raymond L. Information systems design for project management: A data modeling approach. Project Management Journal 1987; 18 (4): 94-99.

Scotsman.com. Athens counting cost of the Olympics. The Scotsman 2005, August 4, http://news.scotsman.com/topics.cfm?tid=1137\&id=1726242005.

Seddon P B, Kiew M-Y. A partial test and development of the DeLone and McLean model of IS success. Proceedings of the Fifteenth International Conference on Information Systems 1994; Atlanta: 99-110.

Shenhar A J, Levy O, Dvir D. Mapping the dimensions of project success, Project Management Journal 1997; 28 (2): 5-13.

Taylor S, Todd P. Understanding information technology usage: A test of competing models. Information Systems Research 1995; 6 (2): 144-176.

Teng J, Calhoun K. Organizational computing as a facilitator of operational and managerial decision making: An exploratory study of managers' perceptions. Decision Sciences 1996; 27 (4): 673-710.

Teo T S H, Wong P K. An empirical study of the performance impact of computerization in the retail industry. Omega 1998; 26 (5): 611-621.

Torkzadeh G, Doll W J. The development of a tool for measuring the perceived impact of information technology on work. Omega 1999; 27 (3): 327-339. 
Tse, A. Comparing the response rate, response speed and response quality of two methods of sending questionnaires: E-mail vs. mail. Journal of the Market Research Society 1998; 40 (1): 353-361.

van der Meijden, M J, Tange H J, Troost J, Hasman A. Determinants of Success of Inpatient Clinical Information Systems: A Literature Review. Journal of the American Medical Informatics Association 2003; 10 (3): 235-243.

Wang RY, Strong D M. Beyond accuracy: What data quality means to data consumers. Journal of Management Information Systems 1996; 12 (4): 5-34.

Weill P, Vitale M. Assessing the health of an information system portfolio: An example from process engineering. MIS Quarterly 1999; 23 (4): 601-624.

White D, Fortune J. Current practice in project management - an empirical study. International Journal of Project Management 2001; 20: 1-11.

Wikipedia. Cost Overrun”, http://en.wikipedia.org/wiki/Cost_Overrun, accessed Feb 23, 2007.

Winter M, Smith C, Morris P. Directions for future research in project management: The main findings of a UK government-funded research network. International Journal of Project Management 2006; 24: 638--649.

Wixom B H, Watson H J. An empirical investigation of the factors affecting data warehousing success. MIS Quarterly 2001; 25 (1): 17-41.

Yuthas K, Young S T. Material matters: Assessing the effectiveness of materials management IS. Information \& Management 1998; 33 (3): 115-124. 